\title{
Foresight Development Strategy of the Financial Capacity: Comparative Study of the Ukrainian Agricultural Sector
}

\author{
Oksana Radchenko ${ }^{1}$, Nataliia Semenyshena ${ }^{2}$, Iryna Sadovska ${ }^{3}$, Kateryna Nahirska ${ }^{4}$, Nataliia \\ Pokotylska ${ }^{5}$
}

\author{
${ }^{I}$ National Scientific Center «Institute of Agrarian Economics» \\ Heroiv Oborony st. 10, Kyiv, Ukraine \\ E-mail.oxanarad@ukr.net \\ ${ }^{2,5}$ State Agrarian and Engineering University in Podilya \\ T. Shevshenka st. 13, 32316, Kamianets-Podilskyi, Ukraine \\ E-mail. ${ }^{2}$ natviksem@gmail.com; ${ }^{5}$ tilya777@ukr.net \\ ${ }^{3}$ Lesya Ukrainka Eastern European National University \\ Volya Avenue 13, 43025, Lutsk, Ukraine \\ E-mail.irina_sadovska@ukr.net
}

${ }^{4}$ Lutsk National Technical University

Lvivska st. 75, 43018, Lutsk, Ukraine

E-mail. katya_nagirska@ukr.net

cross $^{\text {ref }}$ http://dx.doi.org/10.5755/j01.ee.31.2.24340

\begin{abstract}
The system of foresight methods is most often used to solve research problems that are distinguished from the continuity of historical chronology. The aim of our study is to search for new approaches to measuring, assessing and forecasting the economic and financial potential of the agricultural sector, in order to develop an adequate public administration strategy. We have set the task to answer what effect this trend will have for the agricultural sector and the economy of Ukraine in the coming years. We used normative-system analysis - an approach that allows to identify measures that stimulate or limit the implementation of a particular scenario for a particular research subject. This method is aimed at formulating policies and foresight strategies, which are implemented by calculating the financial potential of the agricultural industry. The basis of the research was the hypothesis that the financial potential of the macro level should be analyzed according to the current foresight strategy method, which involves (i) identifying the object of forecasting (agrarian sector), (ii) determining the essential conditions (targets that the financial potential for sustainable development should correspond to), (iii) scanning the environment (what resources and types of potential are related to financial), and $(v)$ identifying alternatives and possible future scenarios (building a balance sheet of financial resources). The results of the statistical analysis suggested that the main determinants of the financial potential are: the volumes, structure, and proportions of reproduction. Furthermore, the efficiency and strength of financial potential are compared with the main macroeconomic indicators of rural development. The results revealed that the necessity of state regulation of financial flows connected with the agrarian sector is substantiated by monitoring the process of forming financial flows in a number of key parameters with the aim of observing the equivalence of all management forms to financial resources. This research contributes to the previous literature on Ukraine context, where we proposed ways to improve the quality of financial potential, the conditions for its formation and distribution and redistribution in accordance with the National Concept for the Development of the Agrarian Sector (2015). Additionally, this research will pave the way for the adaptation of foreign experience, including international comparisons of financial flows and state support.
\end{abstract}

Keywords: Foresight Development Strategy; Financial Potential; Institutional Sector; Agrarian Sector; State Regulation; Macro Indicators.

\section{Introduction}

New economic and political realities require a strategic vision from the government of Ukraine for the sustainable development of the agrarian sector. The main role in this process belongs to the resources that form the financial potential in the cycle of the reproduction process. Since the goal of achieving the European level since its accession to the WTO in 2008, the government's ability to regulate macrofinancial processes determines the place and the country's ranking in the global food chain.
The World Bank's Board of Executive Directors approved the decision (2019) to provide Ukraine with a loan of $\$ 200$ million for the implementation of the program to accelerate private investment in agriculture, and it is expected that "an increase in agricultural productivity by $30 \%$ could increase over the next five years GDP by an additional $4.4 \%$ ".

For Ukraine, as an agrarian power, this need is also reinforced by the fact that for a long time the economy developed according to comprehensive five-year national economic plans, and the strategy was formed taking into account the historical dynamics of the main financial 
indicators and were predicted according to the principle of the achieved level.

The pattern is confirmed that "future strategies come from two approaches based on different principles. Some, aimed at rigid patterns, create a limited understanding of the emerging context and are not capable of responding adequately to changes. Others are not tied to templates, they allow you to identify hidden opportunities, derive a wide range of benefits and achieve your goals" (Bussey, 2013).

At the same time, from the end of the 70s, new planning methods appeared in the world, taking into account the Foresight Development Strategy, the possibilities of which have not yet been fully disclosed to the subject of our study financial potential. It is believed that foresight as a modern research methodology "allows you to mobilize available analytical resources and coordinate the actions of stakeholders to increase the country's global competitiveness" (Meshkova \& Moiseichev, 2016).

In turn, it is necessary to improve the methodological base of the study of financial flows and resources to fully disclose the categories of financial potential and the decision-making mechanism in this area using the Foresight research methodology.

\section{Review of Empirical Literature}

Foresight issues are widely represented in world literature. So, Lu, Hsieh, and Liu (2016) in paper "Development trajectory and research themes of foresight", integrates the edge-betweenness clustering technique and key-route main path analysis to analyse the 'broad foresight' literature and retrieved the relevant papers from the Thomson Reuters Web of Science databases and construct the citation network among them.

According to Bourgeois and Sette (2017), actionable foresight in agriculture faces the double challenge of including multiple stakeholders, reaching significant impact and these authors focused on foresight impact.

Nemeth, Dew and Augier, M. (2018) introduced a strategic Foresight Method that was developed for analysing the strategic foresight process of the Hungarian Ministry of Defense. Allan Andersen and Per Dannemand Andersen (2017) proposed that Foresight can contribute to inclusive development by making innovation systems more inclusive. Based on the notion of innovation system foresight, this authors developed an analytical framework that used to study design and processes in foresight cases in two emerging economies: Brazil and South Korea.

Piirainen and Gonzalez (2015) proposed developing (a) theory of foresight, and separated three levels of analysis: one is foresight as knowledge creating activity, second is foresight as a process and as a social/organizational intervention, and foresight as theorizing about the future of a given sociotechnical system.

Rhisiart, Stormer and Daheim (2017) believed that Foresight impact is considered as a key design issue for projects ab initio; dynamic and iterative engagement processes support co-production and facilitate impact prospects.

Aguirre-Bastos and Weber (2018) argued that Foresight is an appropriate instrument to shape innovation systems and support policy-making processes, thus, foresight has attracted interest in developing countries. However, the ability to effectively exploit its results is hampered by the limitations of their governance systems to take into account the complexity in the definition of public policies. In such a context, foresight needs to be more thoroughly integrated into the policy making process to be effective.

Pietrobelli, C., \& Puppato, F. (2016) examined how and to which extent Technology Foresight programs are needed in developing countries given the new prevailing global context and provided preliminary support to this argument by discussing the theoretical foundations and justification of Technology Foresight and industrial strategy, and then reviewing some relevant examples from Brazil, Chile and South Korea.

In Ukraine, the issue of Foresight Development Strategy of the agricultural sector Financial Capacity are little studied.

The financial potential is being investigated and discussed in the literature in a diversity of directions, ranged for example from the potential of agrarian enterprises (Korniichuk, 2015; Hudz, 2015; Prokopyshak, 2016); agricultural production (Hryshova, 2015); financial and credit infrastructure (Radchenko, 2018), the agrarian sector (Trusova, 2017) and the state policy (Portna, 2017).

At the global level, due to the concentration of financial potential in new entities controlling the deeper processing of products, there is a new type of inequality, indicating a veiled link between politics and money, and the concentration of food chains. The formation of a "virtual" financial derivative of agrarian production, which affects investment decisions on objects of significant socio-ecological value, took place (Clapp, 2014).

Since private capital does not invest in agriculture without guarantees and support from the state, states practice different levels of regulation of private finance in the sector (Martin, 2015). Changing the conditions for state support for agriculture (Matthews, 2016) is manifested in the fact that trade in products is increasingly being affected by agricultural policies in non-OECD countries, even if the OECD countries still have an advantage in production. This led to the need for emergency support measures (EU, 2015), providing $70 \%$ of direct payments in advance, as an anti-crisis measure and the definition of a number of technical procedures to increase the flexibility of financial flows to the agro-sector.

The EU legislator instructed the European Commission to assess the effectiveness of direct payments of state support to farmers (Koester, 2016). It is established that the current methodology of regulation of the industry financial potential does not have clearly defined goals and indicators, does not solve the problem of identifying the effectiveness of payments; does not make it possible to evaluate budget support by type of payment.

Why are studies of the methodology of calculating and defining the concept of financial potential so important for the agricultural sector? In addition to these general issues of the need for food security, almost all agrarian countries in the world have faced the problem of the importance of state regulation of financial flows, because, even private investment in the industry in advance receive guarantees from the state. In this regard, resource planning and financial management of the industry provides an indisputable advantage for managing reproduction and overall economic growth. 
The most valuable part of scientific research is the development of a substantiated economic forecast based on the corresponding growth rates of the national and world economy. This macroeconomic indicator traditionally takes into account agriculture, the specific gravity of which is the basis for attributing a particular country to the corresponding type of economic development.

\section{Research Methodology}

The study was based on the hypothesis that the Foresight Strategy Method involves determining the object of forecasting (the agrarian sector), determining the essential conditions (targets that the reproduction of the financial potential for sustainable development should correspond to), scanning the environment (which resources and types of potential to relate to), identifying alternatives and possible future scenarios (building a balance of financial resources).

In the article, we made an attempt to combine these three approaches and assess the prospects for improving the methodological base of the study of financial potential by using elements of the Foresight methodology.

Sources of data are official sites of the State Statistics of Ukraine and OECD, the State Treasury, the National Bank of Ukraine, regulations on the control of agricultural development - the Law of Ukraine on State Support of Agriculture (2004), the Annual Law on the State Budget, and the Strategy development of Ukrainian agriculture for the period up to 2020 (2012). Data on the financial potential of agrarian enterprises are calculated on the basis of statistical reporting provided by micro, small, medium and large enterprises by agricultural activity codes. Data on the savings of the rural population were not taken into account.

\section{Results and Discussions}

Agrarian policy is defined as a set of principles and actions that the state performs in solving a set of problems related to the functioning of the agro-industrial complex (agrarian production, infrastructure, processing, markets, consumption, export).

This is due to the fact that agriculture takes $70 \%$ of the country's territory, it accounts for more than $30 \%$ of exports, $17 \%$ of GDP, it forms $11 \%$ of budget revenues. More than $19 \%$ of labour resources are concentrated here, production is carried out on $70 \%$ of the total land fund of the country and over $90 \%$ of agricultural land, the region owns $6 \%$ of fixed assets of the economy. Therefore, the country's economy as a whole depends on the level of economic development of agriculture. A special role and place of agriculture in the economy of Ukraine determines that $1 \%$ of the growth in agricultural production provides 3-4\% of GDP growth.

The patterns of this process in Ukraine and the world are presented in table 1 .

The share of the agricultural sector in the total expenditures of the State budget for economic activity from $16.7 \%$ in 2011 increased to $23 \%$ in 2017 Among the sectors of the economy in 2011-2017. Budget expenditures stability for financing is maintained only in the agricultural sector.
Table 1

Dynamics and Structure of Agricultural GDP in Individual Countries, for 1999, 2018, dollars, \%

\begin{tabular}{|l|c|c|c|c|}
\hline Region & \multicolumn{2}{|c|}{$\mathbf{1 9 9 9}$} & \multicolumn{2}{c|}{$\mathbf{2 0 1 8}$} \\
\hline & $\begin{array}{c}\text { GDP per } \\
\text { capita, } \\
\text { USD }\end{array}$ & $\begin{array}{c}\text { \% of } \\
\text { agriculture } \\
\text { in GDP }\end{array}$ & $\begin{array}{c}\text { GDP per } \\
\text { capita, } \\
\text { USD }\end{array}$ & $\begin{array}{c}\text { \% of } \\
\text { agriculture } \\
\text { in GDP }\end{array}$ \\
\hline World & 6800 & 5,2 & 11298 & 3,4 \\
\hline Europe & 19637 & 2,2 & 35531 & 1,4 \\
\hline England & 21280 & 0,8 & 42490 & 0,6 \\
\hline Greece & 13900 & 8,3 & 20324 & 3,7 \\
\hline France & 23300 & 3,3 & 41446 & 1,6 \\
\hline Poland & 7200 & 5,0 & 15424 & 2,4 \\
\hline Latvia & 3113 & 6,3 & 19090 & 2,7 \\
\hline Estonia & 4119 & 3,9 & 22927 & 2,2 \\
\hline US & 33900 & 2 & 62641 & 0,9 \\
\hline Vietnam & 1850 & 26,0 & 2568 & 14,6 \\
\hline Ukraine & 2220 & 12,0 & 3095 & 10,1 \\
\hline
\end{tabular}

https://data. worldbank.org/indicator/NY.GDP.PCAP.CD? locations $=G B$

A regression analysis of the linear trend of agricultural spending with a confidence of $77 \%$ indicates an annual increase in funding of UAH 17 billion, while direct expenses in the amount of almost UAH 6 billion, or $\$ 230$ million, are planned for 2019 (in 2014, million USD).

The policy of state regulation of agriculture in Ukraine according to the OECD methodology is quite unique. If in all countries of cooperation strict monitoring is carried out and agriculture is maintained, in Ukraine it is taxed, and after a number of years' government support is negative, due to the difference in domestic and world prices for exported products and it is a kind of implicit taxation of the sector (Agricultural Policy Monitoring and Evaluation, 2018). That's why we chose it as the object of study.

\section{Definition of the Category of Financial Potential}

According to prior research, it is interpreted as a symbiosis of the concepts of "financial institutions", "financial resources/flows", "financial policy" in (non)system hierarchy. In the most general terms, it "reflects the availability of conditions for an expanded reproduction of the economy of the country as a whole and a separate subject" (Kucher, 2014); is interpreted as an economic system that "has distinctive features: structural, communicative, hierarchical, ability to develop"; is an estimated indicator as a "set of available means and opportunities in a particular economic area" (Prokopyshak, 2016); and manifests itself as a set of own and borrowed resources, aimed at effective social and economic development that provides financial stability.

All the available resources that have a cost estimate, or one that can be calculated, are included in the components of the financial potential. Due to a significant number of components, one can state its dependence on many factors, both economic and non-economic, which should be investigated. As it can be noted, many macro and micro levels of indicators affecting its regulation are embodied in the category of "financial potential".

According to the results of studies, it was found that the financial potential of the agricultural sector can be defined as: the ability to mobilize the financial resources of agricultural enterprises as a result of interaction with the state, rural population and market agents; valuation of the 
total financial assets of these economic entities; basic model of potential sources of financing sustainable agricultural development (Radchenko, 2019).

In more detail, the components of financial potential are given in an empirical method for its determination.

\section{An Empirical Methodology for Determining the Financial Potential of the Agrarian Sector}

Relying on the current practice of evaluating financial potential, which suggested in this paper, as well as our previously published approaches to financial agrarian infrastructure (Radchenko \& Lazutina, 2018), the most capacious components of it are allocated: budget expenditures for the agrarian sector; agricultural tax privileges, financial resources of agrarian enterprises; resources of the financial market (infrastructure); investment resources for the industry.

Thus, the methodology for determining the financial potential of the agricultural sector is based on its ability to grow and develop due to the totality of available internal and external financial resources, as well as conditions created by the state for their formation, distribution and redistribution within the agrarian and related sectors of production and of the financial market as links forming the value chain of agriculture.

The general procedure for calculating the financial potential of the agrarian sector can be presented in a sequence of total estimation of the enumerated resources (formula 1):

$$
\mathbf{F P}=\sum(\mathbf{F R m}+\mathrm{FRs}+\mathrm{FRt}+\mathrm{FRe}+\mathrm{FPi})
$$

where FP - financial potential of the agrarian sector, UAH billions; FRm - financial resources of the market, FRs - budgetary resources of the state; FRt - financial resources of tax perks; FRe - financial resources of enterprises; FRi investment resources in monetary terms.

\section{Estimation of Financial Potential}

In accordance with the given methodology, a general (fragmentary) estimation of the FP of the agrarian sector in dynamics over a number of years was carried out as shown in Figure. 1.

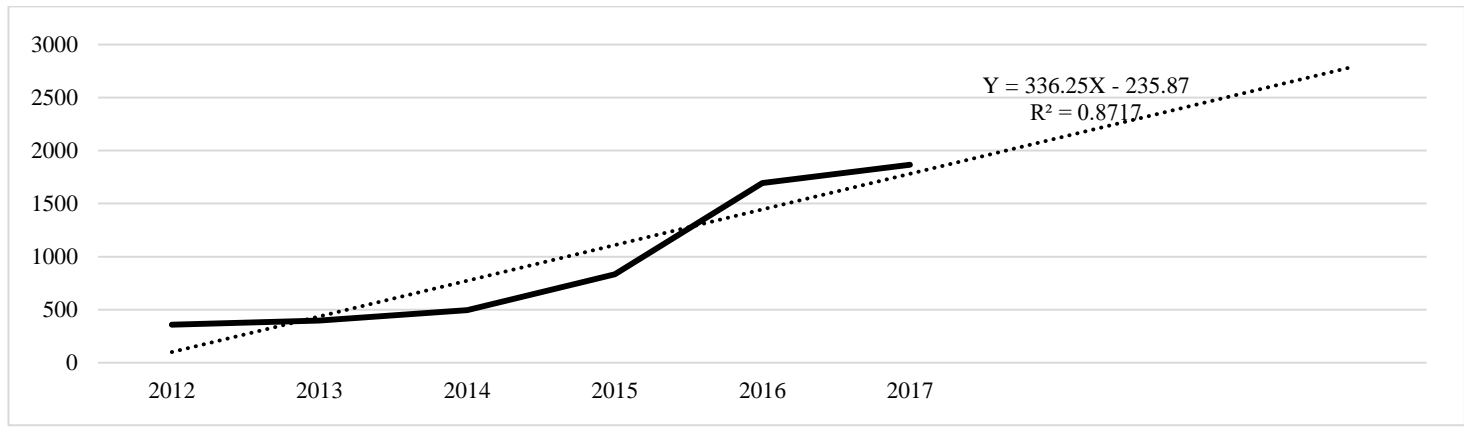

Figure 1. Dynamics of the Financial Potential of the Agrarian Sector for 2012-2017, UAH Billion

Source: Based on public information data of Public services, for 2017, the previous data

The correlation analysis of financial potential shows that according to the linear regression equation within the framework of its analysed structure the annual growth by UAH 336 billion is expected in the next three years, with an adequacy $\left(\mathrm{R}^{2}=0.8717\right)$ with a volume of UAH 1,870 billion by 2017 . However, as the results of correlation analysis show, part of the selected factors of the FP structure includes a double account (loans, investments, savings).

For the agrarian sector, it is also the indices of agricultural production growth, sales prices of the industry, the state of profit before taxation and others, some of which are shown in Figure 2.

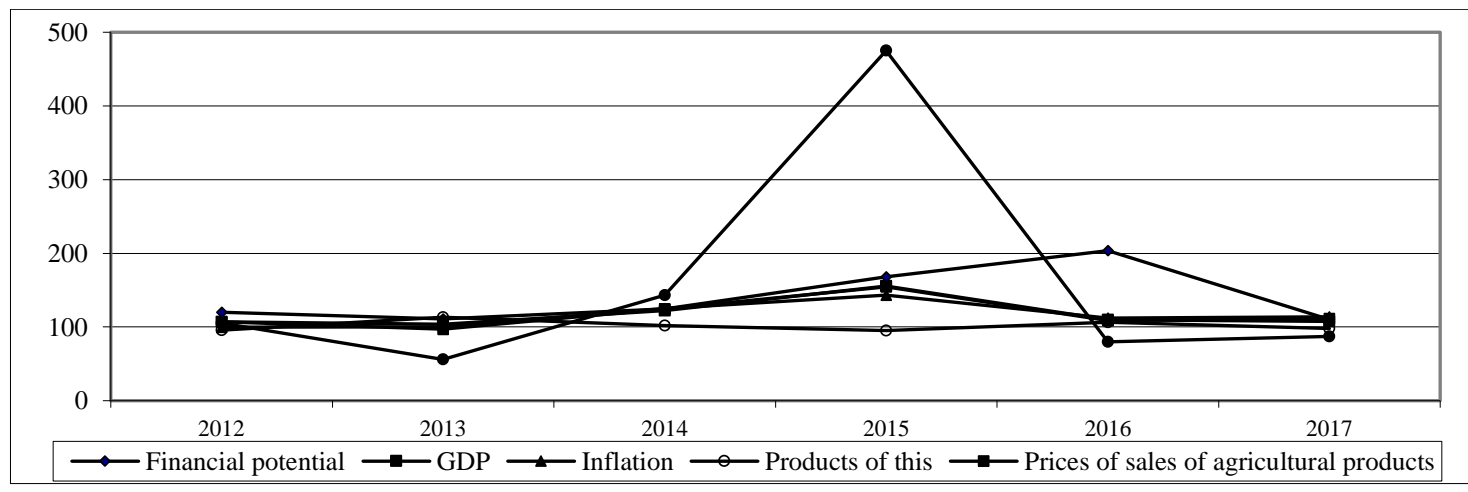

Figure 2. Dynamics of Indices of the Financial Potential of the Agrarian Sector and Certain Economic Factors, \%. Source: Based on the data of the State Statistics Service

Comparison of the chain indexes of financial potential, agricultural products, agriculture GDP, prices of the agricultural enterprises sales of their products, and inflation shows that the greatest impact on the analysed category was made by the index of profit before tax. 
In 2015, there was a significant increase, which enabled manufacturers to increase working capital in subsequent periods, and this was reflected in the growth of FP.

From sources available for analysis of the FP structure (Figure 3), it is determined that the financial resources of agrarian enterprises account for the largest share - $90 \%$ in 2017 and $70 \%$ in 2012, while the state, market, and investment resources remain insignificant even in aggregate.

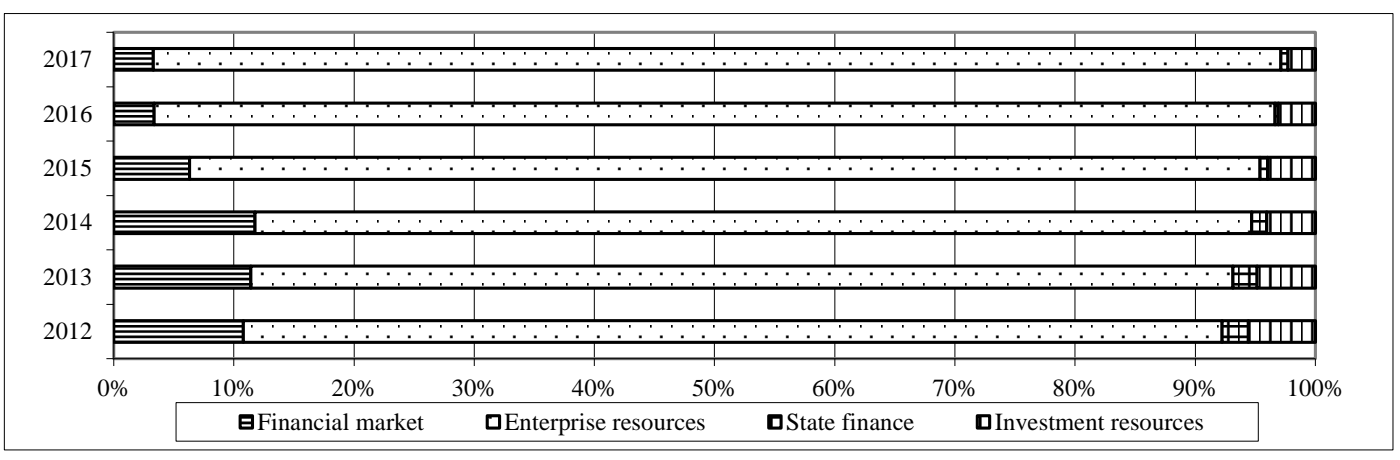

Figure 3. Dynamics of the Financial Potential Structure of the Agrarian Sector for 2012-2017,\%

Source: Based on the data of the State Statistics Service

The dynamics of the structure of financial resources of enterprises for the period of 2012-2016 confirms the conclusion that financial potential has been increasing since 2015 due to the price and inflation factors and increase in profits at constant volumes of production, there is an increase in the share of borrowed resources in liabilities and current assets in the asset of balance from 2012 to 2016.

The financial flows of agrarian enterprises are the most significant in the structure of the potential. The dynamics and structure of the agriculture gross value added for 20112016 is shown in Table. 2.

Table 2

Financial Flows for the Formation of Net Profit of Agriculture for 2012-2016, UAH Million

\begin{tabular}{|l|l|c|c|c|c|c|}
\hline & Indexes & $\mathbf{2 0 1 2}$ & $\mathbf{2 0 1 3}$ & $\mathbf{2 0 1 4}$ & $\mathbf{2 0 1 5}$ & $\mathbf{2 0 1 6}$ \\
\hline 1 & Gross value added & 109227 & 128501 & 156385 & 232368 & 270395 \\
\hline 2 & Capital consumption & 7251 & 9315 & 9981 & 14010 & 16315 \\
\hline 3 & Net value added (1-2) & 101976 & 119186 & 146404 & 218358 & 254080 \\
\hline 4 & Pay & 25789 & 29823 & 30461 & 34038 & 39731 \\
\hline 5 & Other taxes & 1294 & 1333 & 1596 & 3078 & 1934 \\
\hline 6 & Other subsidies & 1125 & 624 & 279 & 1732 & 1676 \\
\hline 7 & Factor Income (3-5 +6) & 101807 & 118477 & 145087 & 217012 & 253822 \\
\hline 8 & Net current income / mixed income (3-4-5+6) & 76018 & 88654 & 114626 & 182974 & 214091 \\
\hline
\end{tabular}

Source: Based on the data of the State Statistics Service

As we can observe, in the structure of financial potential, the own funds of agrarian enterprises remain as the main source. At the same time, enterprises are increasingly attracting external resources. As can be seen from Figure 4, the share of loan sources from $50 \%$ in 2012 grew to $80 \%$ in 2016.

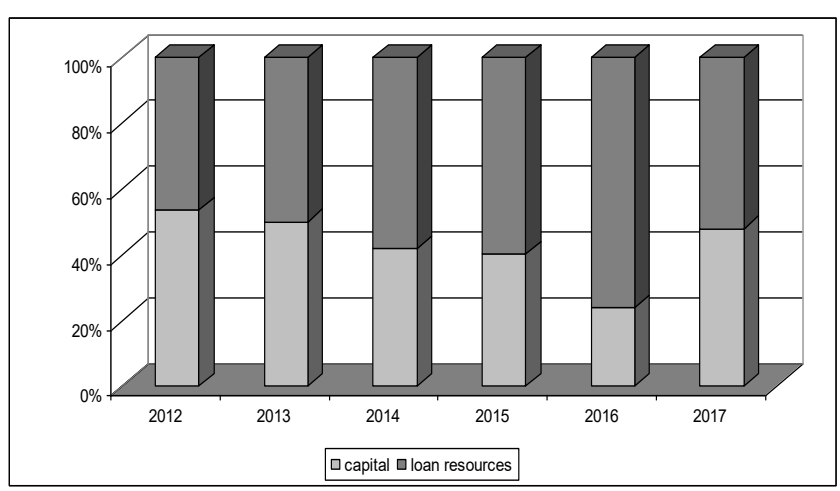

Figure 4. Structure of Own and Attracted Sources of Financial Potential of Agricultural Eenterprises for 2012-2017, \%

Source: Based on the data of the State Statistics Service
If, for example, in 2016 the average growth rate in Ukraine was $10 \%$, some regions still have this indicator at the level of more than $20 \%$. At present, the considered factors of the formation of financial flows are the most significant also according to the influence on the formation of regional policy.

\section{Efficiency Indices}

In the process of analysis, it is important to form points of control of the financial potential, being the closest to reality, and serving simultaneously as a monitoring. It should be noted that the assessment of the potential by the structural method (formula 1, Figure 2), is the simplest. However, it is necessary to take into account the properties of their use and the reproduction and build-up requirements.

The study of the financial potential of the agrarian sector (Figure 5) in the relative performance indicators according to the chain indexes shows its advantages if compared to the indices of gross value added and indices of agricultural products, especially since 2016.

In foreign practice, the costs and benefits are being analysed directly from financial regulation. In particular, a rather rapid and radical intellectual change in the field of 
financial regulation and macroeconomic policy after the 2008 financial crisis may be explained by the institutional political differences between the subsystems of micro and macroeconomics (Baker 2015, p. 342).

The main indicators for assessing the level of financial potential are given in Table. 4 , they reflect the specifics of the certain level (agrarian enterprises, the financial market, investors, the banking system, the state) and are detailed for each.

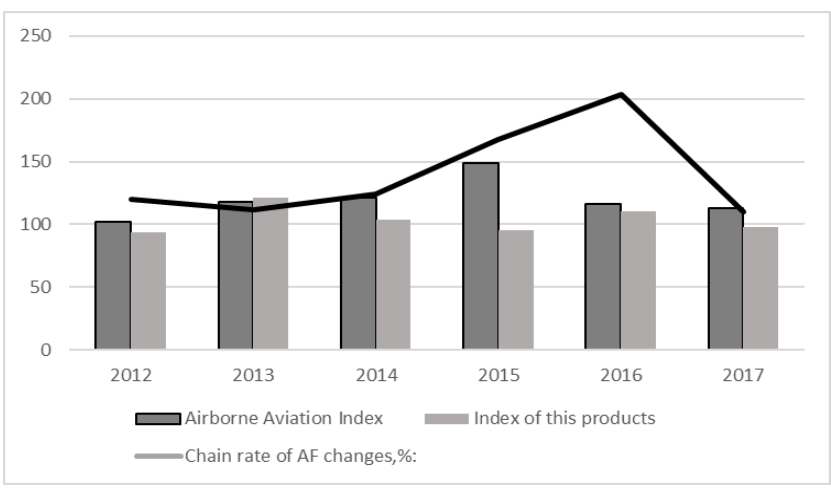

Figure 5. The Efficiency of the Financial Potential of the Agrarian Sector, 2012-2017

Source: Based on the data of the State Statistics Service

It is expected that the financial potential of the agrarian sector can grow annually by UAH 336 billion (18\%) in the next $3-5$ years, in 2020 it will grow 3.2 times against the level of 2015 .

\section{Foresight Strategy}

Foresight, as a research method, is an effective tool for selecting priorities and is defined as "systematic attempts to assess the long-term prospects for the development of science, technology, economics and society in order to identify strategic areas for scientific and technological research that can bring the greatest social and economic benefits" (Ben Martin, 1995) and is currently used for all socio-economic development problems.
Foresight's capacious research site is the Foresight project (Foresight, 2007-2019), which reveals the following topics: the Foresight methodology and best practices; longterm priorities of social, economic and scientifictechnological development; innovative strategies at the national, regional, sectoral and corporate levels; development of national innovation systems; technology change and its effects on economics, politics and society; innovation management in business environments, etc.

For the Ukrainian agrarian sector, the method is initiated as a foresight strategy for socio-economic development of the medium-term (until 2020) and longterm (until 2030) time horizons (Zghurovskyi, 2016).

In particular, the agrarian foresight programs of Kazakhstan stated that in the future development of science and technology can only be achieved by ensuring conditions for the mobilization of resources for the promotion of technological development in selected priority areas, which, on the one hand, should create the preconditions for attracting private capital to finance key developmental areas for the country.

By the foresight strategy, the staging problem for the purpose of this study is the need to regulate financial potential due to the lack of effective structural reforms in the policy of state support. As a result, the estimation of financial potential is carried out unsystematically, there are no indexes and indicators of efficiency; there is a significant gap in the processes of reproduction of financial flows and financial balance, current domestic methods of determining the volume do not correlate with foreign ones; there is an uncompetitive distribution of financial resources by management, there is a weak fiscal position of the state, poor state support of integrated agricultural structures, agrarian science and innovations, small enterprises, etc.

According to UKRINTEI (UkrINTEI, 2016) recommendations for scientific forecast-analytical research using foresight methods, for our research, the following algorithm has been formed (Figure. 6).

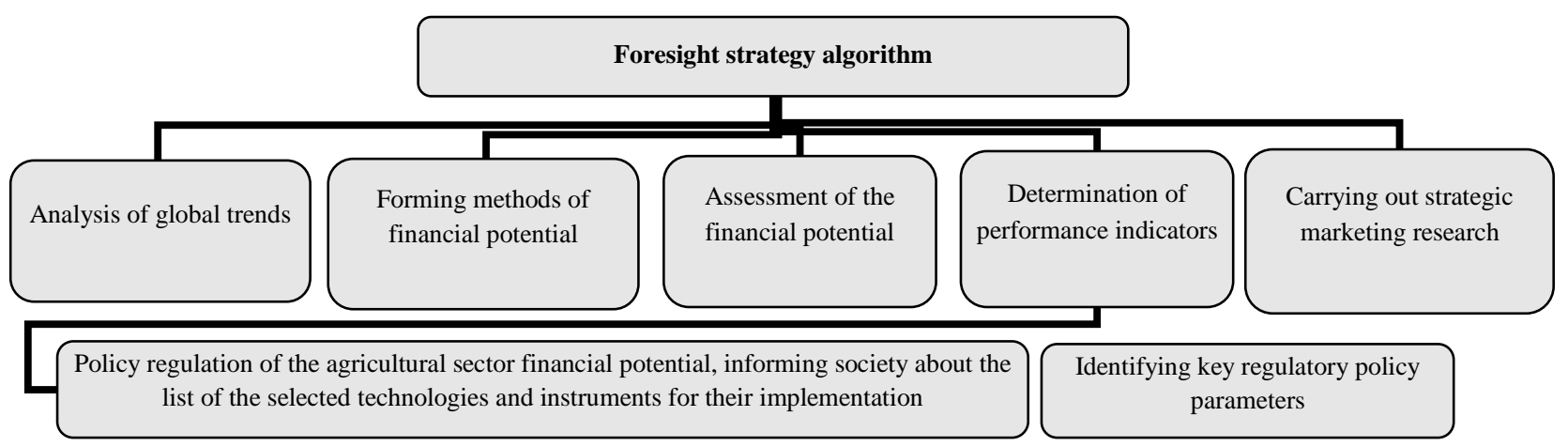

Figure 6. Algorithm of Foresight Strategy Research of Financial Regulation of the Ukrainian Agricultural Sector Source: Based on (UkrINTEI, 2016)

The usage of the above algorithm and the general methodology of the foresight, adapted to the agricultural sector, developed by researchers (Stukach \& Volkova, 2013), allows one to plan the following steps: (i) analysis of global trends and the definition of the studied thematic field, (ii) selection of research methods (methods, evaluation, indicators), (iii) conducting strategic marketing research and determining critical points of change in the situation (key parameters of regulatory policy), (iv) the formation of alternative scenarios strategy development, and (v) recommendations on the developed strategy. 
Blocks of the System for Assessing the Financial Potential of the Agrarian Sector

\begin{tabular}{|c|c|c|}
\hline Indicators & Purposes & Application \\
\hline state & $\begin{array}{l}\text { determining the amount and structure of incomes, savings, and financial } \\
\text { assets; } \\
\text { determining the state of financial resources of the agrarian sector: } \\
\text { - financial potential of economic entities } \\
\text { - financial potential of the state } \\
\text { - credit potential } \\
\text { - tax potential } \\
\text { - savings potential } \\
\text { - investment potential, etc. }\end{array}$ & $\begin{array}{l}\text { adjustment of existing forms and methods of state } \\
\text { regulation of agrarian economics; } \\
\text { determining the mechanisms and tools for the } \\
\text { formation of macroeconomic indicators of the } \\
\text { industry; } \\
\text { formation of the financial balance of the agrarian } \\
\text { economy } \\
\text { level of rural life; } \\
\text { state of the financial infrastructure }\end{array}$ \\
\hline efficiency & $\begin{array}{l}\text { analysis of the financial flows; } \\
\text { assessment of budget capacity; } \\
\text { assessment of tax capacity; } \\
\text { credit solvability assessment; } \\
\text { preventive estimation of unprofitableness; } \\
\text { analysis of the emergence of crisis phenomena; } \\
\text { analysis of the dynamics of the attraction of investments; } \\
\text { analysis of the intensity of cash flows; } \\
\text { determination of optimal mechanisms for the realization of financial } \\
\text { potential }\end{array}$ & $\begin{array}{l}\text { estimation of the optimal level of financial } \\
\text { potential; } \\
\text { the growth in volumes of lending, insurance, } \\
\text { investment; } \\
\text { incomes growth of the food chain participants } \\
\text { assessment of the link between the potential and the } \\
\text { factors that shape this process } \\
\text { analysis of the factors influence on the process of } \\
\text { the potential formation }\end{array}$ \\
\hline $\begin{array}{l}\text { development } \\
\text { trends }\end{array}$ & $\begin{array}{l}\text { macroeconomic regulation of the industry within the national economy; } \\
\text { optimization of financial relations; } \\
\text { relevance assessment of the development projects; } \\
\text { planning of production, market and consumer behaviour; } \\
\text { formation of the information environment of development }\end{array}$ & $\begin{array}{l}\text { monetary and non-monetary goals; } \\
\text { formation of industry development strategies; } \\
\text { formation of a competitive market environment; } \\
\text { integration into the global financial space } \\
\text { the financial ensuring of food security }\end{array}$ \\
\hline
\end{tabular}

Source: Based on: (Portna, 2017)

Blocks of performance indicators include the calculation of state indicators, efficiency and development trends, the development of monitoring and publication of data in these areas.

The given research results suggest that the methodology of approaches to assessing the financial potential of the Ukrainian agrarian sector under the conditions of systemic reforms should be based on the continuity of the traditional one and take into account the world tendencies of evaluation.

This implies that the former includes the interaction of these constituents and the continuity of the management of the interconnection of the elements of potential. The actual potential is formed under the influence of three groups of factors: financial, economic, social and managerial with a set of corresponding parameters.

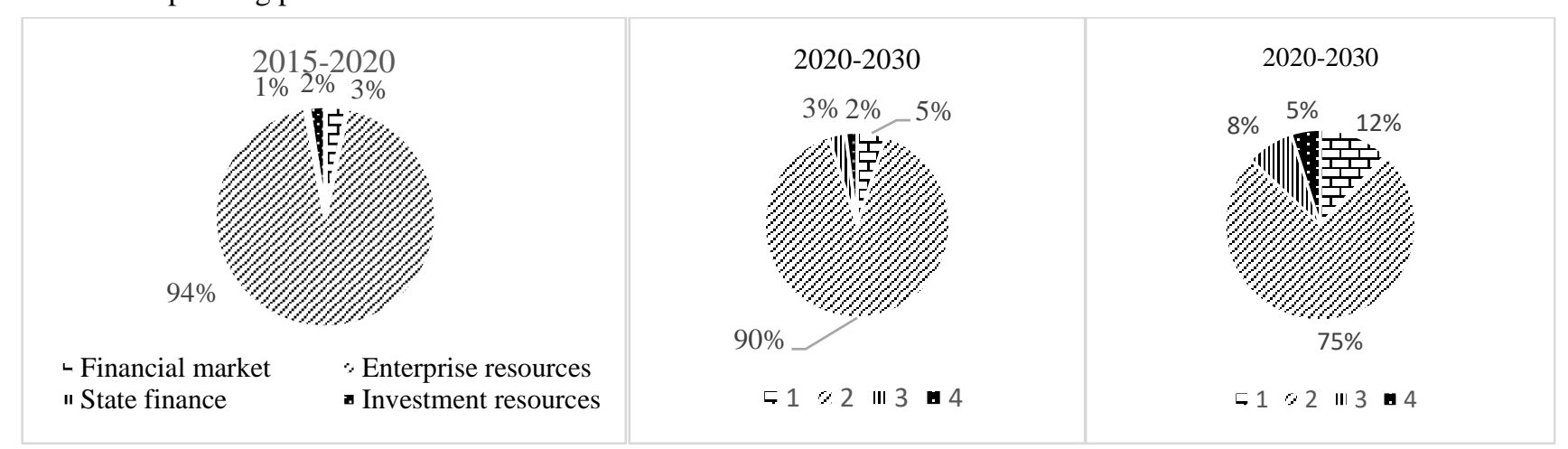

Figure 7. Diagram of Prediction of the Future Structure of the Financial Potential of the Agrarian Sector (up to 2030), \% Source: calculated by authors

\section{Determining the Strategy of Regulation of Financial Potential}

The growth of the financial potential by 2030 is projected to be 2.2 times against the calculated level of 2020 and 3.2
For the needs of the state regulation, it is necessary to determine the criteria of financial potential, its structural components, a set of specific indicators, efficiency monitoring programs. The assessment of the level of financial potential should be based on adherence to the principles of the adequacy of the evaluation parameters of the essence of the processes that are the subject of analysis; complexity (taking into account all factors influencing financial potential); allocation of main elements; the sequence of evaluation measures.

Using the developed foresight methodology, especially the online platform for its modelling and visualization (Zghurovskyi, 2016), Figure 7 depecits the prediction of the future structure of the financial potential of the agrarian sector for the period up to 2030 . 
volume of financial potential for its most significant components amounted to UAH 1,822 billion (USD 68 billion), then for the period up to 2020, its growth up to UAH 2810 billion (USD 105 billion), or $54 \%$ growth is prognosticated. By 2030, under a neutral scenario, under other equal conditions, it is expected to grow 3.2 times against the average potential for 2015-2020.

Methodological approaches to the key parameters of the policy of regulation of financial potential in general and its individual components should include the definition of criteria of financial potential, the choice of certain indicators, their thresholds, monitoring of the certain indicators, the comparison of actual values of certain indicators with thresholds, analysis of the results obtained, forecasting of the most important groups of indicators.
Currently, financing from the State Budget to the branch is as shown in Figure (8) and in the general expenditures of the State Budget does not exceed $3 \%$. At the same time, the industry's contribution to the economy in 2017 was $10.2 \%$, as well as on average for 2011-2017.

According to experts (Zghurovskyi, 2016), the sector, under its modernization and re-equipment with technologies of 5-6 technological processes, can provide the largest contribution to the economy of Ukraine at the level of $19 \%$ by 2020 and $24 \%$ by 2030. Prerequisites for this are the favourable climate of Ukraine; on the territory of Ukraine, which covers up to $0.5 \%$ of the earth's land, about $20 \%$ of the world's chernozems are located; rising food crisis in the world; the deep traditions of the Ukrainian population in the field of agrarian production. However, the steps to be taken in the agrarian sector are given in Table 4, namely (start of activating the cluster years 2016-2020).

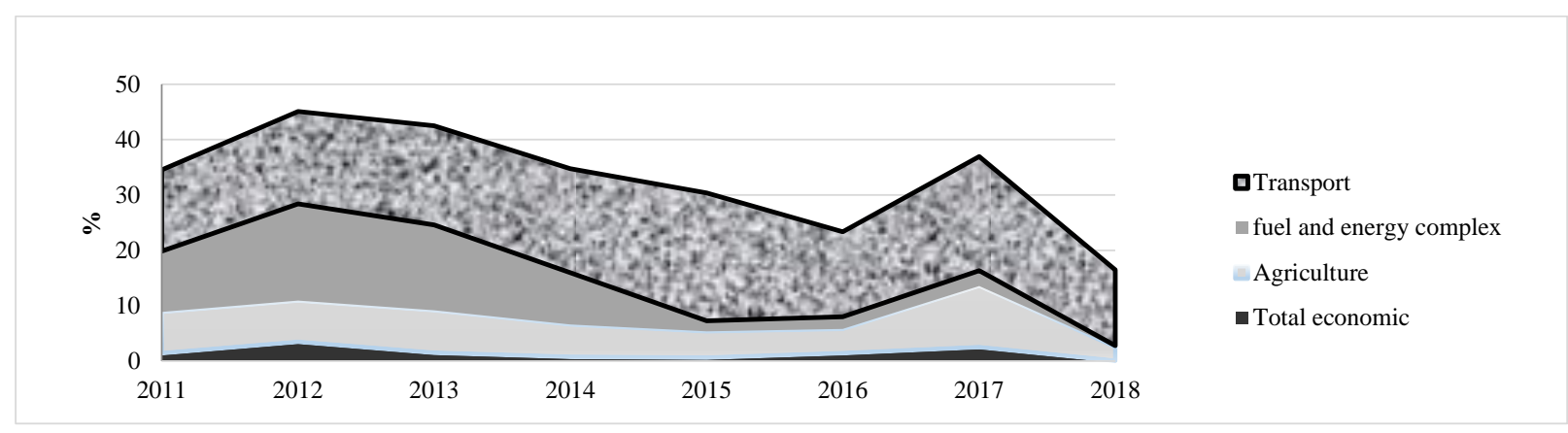

Figure 8. Expenditures of the State Budget for economic activity in 2011-2017, UAH billion

* Data in 2018 - for 9 months

Source: calculated on the basis of data of the State Treasury

Table 4

Actions of the Authorities on Activation of the Agrarian Cluster, (up to 2020)

\begin{tabular}{|c|c|c|}
\hline Actions of power (reforms) aimed at activating the cluster of the economy & $\begin{array}{l}\text { Investment volume } \\
2016\end{array}$ & \begin{tabular}{|c|} 
Investment volume \\
$\mathbf{2 0 2 0}$ \\
\end{tabular} \\
\hline $\begin{array}{l}\text { D1.1. Development and implementation of a progressive agrarian policy of the state aimed at } \\
\text { creating a competitive environment for small farms (up to } 1000 \text { hectares of land), the one of an } \\
\text { average (up to ten thousand hectares of land) and the large (tens and hundreds of thousands of } \\
\text { hectares of land) scales, reorientation of the agrarian sector of Ukraine mainly to production of } \\
\text { high-quality, organic food with a high degree of processing, the introduction of a transparent, state- } \\
\text { and civil society controlled land market, leading an active and effective state policy in the foreign } \\
\text { markets in order to reach them and their expansion in the component of export of high-quality, } \\
\text { organic food products of high level of processing }\end{array}$ & $\begin{array}{l}5-8 \\
\text { UAH billion }\end{array}$ & $\begin{array}{l}12-15 \\
\text { UAH billion }\end{array}$ \\
\hline $\begin{array}{l}\text { D1.2. Transition of the agrarian sector of Ukraine to the technology of the 5th and 6th structure } \\
\text { aimed at substantially (in several times) raising the productivity of agricultural labour, decreasing } \\
\text { its power consumption, increasing the added value and quality of the food being produced }\end{array}$ & $\begin{array}{l}1400 \\
\text { UAH billion }\end{array}$ & $\begin{array}{l}2300-4500 \\
\text { UAH billion }\end{array}$ \\
\hline $\begin{array}{l}\text { D1.3. Creation and the wide-scale introduction of a modern system of hydro melioration, } \\
\text { fertilization and plant protection }\end{array}$ & $\begin{array}{c}150 \\
\text { UAH billion }\end{array}$ & $\begin{array}{c}300-500 \\
\text { UAH billion }\end{array}$ \\
\hline $\begin{array}{l}\text { D1.4. The introduction of a sectoral financial and credit system for the agrarian sector of Ukraine, } \\
\text { including a land bank, the creation of a system of insurance for the agro-industrial complex, a } \\
\text { significant increase in the country's credit-investment level in the agricultural sector }\end{array}$ & $\begin{array}{l}95-115 \\
\text { UAH billion }\end{array}$ & $\begin{array}{c}62-135 \\
\text { UAH billion }\end{array}$ \\
\hline
\end{tabular}

Source: calculated on the basis of (Zhurovskyi, 2016)

Step 1. Development and implementation of a progressive agrarian state policy, aimed at forming a competitive environment for all forms of economic activity, support for its weakest part - small business.

Step 2. The transition of the Ukrainian agrarian sector to high technology with the purpose of significant increase of productivity of agricultural labour, decrease of its power consumption of, increase of the added value, and this is a deepening of processing of products and export not of the raw materials but goods. It provides support for processing agricultural products and marketing as a way to integrate all the components of the production chain from production to implementation and promote further improvement of agricultural structures and the competitiveness of the raw material sector. 
Step 3. Development of the sectoral financial and credit system for the agrarian sector of Ukraine, including the land bank, the creation of a system of insurance for the agroindustrial complex, a significant increase in the country's credit-investment level in the agricultural sector. This involves stimulating investment in agriculture.

Step 4. Development of rural areas and human capital by means of providing preferences for vocational training, social security etc.

Thus, the foresight method allows systematizing information on the state and possible ways of improving the regulation of the financial potential of the agrarian sector.

According to the results of the foresight of the research method, it was found that by 2030 will increase 8 times compared to 2015. For the period of 2020-2030, the annual growth, calculated on the basis of correlation methods, is projected at the level of UAH 345 million.

\section{Conclusions}

Thus, for the first time in Ukraine, a comparative study of the use of foresight honey to determine the strategy for developing financial potential using the example of the agricultural industry was carried out. It has been established that the traditional methodology can be useful for a short planning period of 3-5 years, provided that over the next period selected by the analysis base, the positive dynamics of the development of the phenomenon remained. However, as our example shows, the rapid decline in the level of financial resources of agricultural enterprises in 2017 greatly affects the results of foresight and cannot reveal the big picture.

In this case, in addition to traditional empirical research methods, there is a need to apply foresight planning technology, which provides more flexible data, is elastically linked to the overall economic development of the country and industries, and thus allows managing results and shaping an effective policy of state regulation of the industry.

The results of testing the Foresight methodology prove its effectiveness in relation to the study of potential assessment, some difficulties exist only in the systematization of statistical information.

In order to obtain reliable information for a full and comparative analysis of the country's financial potential, its level of development and the efficiency of use, quantification and growth prospects, and to solve issues related to the development of the country's financial and economic policy, it is necessary to improve the methodology of calculations, taking into account all the factors and components mentioned in the study. The strategy of developing financial potential regulation can be fairly predicted with foresight methods.

Achieving positive results in solving problems of financial potential will be the basis for achieving high living standards of the population, international competitiveness ratings of Ukraine, successful integration into the world financial and economic community.

\section{References}

Financial capacity of the public sector to implement the United Nations Millennium Declaration, Report of the Secretariat United Nations E/C.16/2002/6 (2002). p. 11. Retrivied from http://unpan1.un.org/intradoc/ groups/public/ documents/un/ unpan 004345.pdf.

Zghurovskyi, M. Z. (2016). Forsait ekonomika Ukrainy: serednostrokovyi (2015-2020 roky) i dovhostrokovyi (2020-2030 roky) chasovi horyzonty». Kyiv, NTUU «KPI». Retrivied from http://wdc.org.ua/sites/default/files/WDC-IASAFORESIGHT-2016.pdf

«Forsait v Ukraini». Retrivied from http://www.uintei.kiev.ua/foresight/ua/index.php

Agricultural Policy Monitoring and Evaluation 2018. https://doi.org/10.1787/agr_pol-2018-en

Baker, A. (2015). Varieties of economic crisis, varieties of ideational change: how and why financial regulation and macroeconomic policy differ. New Political Economy, 20 (3), 342-366. https://doi.org/10.1080/1356 3467.2014. 951431

Bussey, M. (2013). Kontseptual'nye osnovy Forsayt-issledovaniy i ikh effekty: klassifikatsiya i prakticheskoe primenenie [Conceptual Frameworks of Foresight and Their Effects: Typology and Applications]. Foresight-Russia, 7(3), 64-73. https://doi.org/10.17323/1995-459X.2013.3.64.73

Clapp, J. (2014). Financialization, distance and global food politics. Journal of Peasant Studies, 41 (5), $797-814$. https://doi.org/10.1080/03066150.2013.875536

Hryshova, I. Yu., Mytiai, O. V., \& Kuzhel, V. V. (2015). Otsiniuvannia chynnykiv formuvannia finansovoho potentsialu ahrarnoho vyrobnytstva. Aktualni problemy ekonomiky, 10, 169-175.

Koester, U. (2016). The use of CAP impact indicators for policy evaluation. Retrivied from http://capreform.eu/the-use-ofcap-impact-indicators-for-policy-evaluation-2/

Korniichuk, H.V. (2015). Teoretychni osnovy rozvytku finansovoho potentsialu ahroformuvan. Pershyi nezalezhnyi naukovyi visnyk, 5, 60-62.

Kucher, H. (2014). Finansovyi potentsial ekonomichnoho rozvytku: teoretychnyi aspect. Visnyk Kyivskoho natsionalnoho torhovelno-ekonomichnoho universytetu, 4, 92-105. 
Oksana Radchenko, Nataliia Semenyshena, Iryna Sadovska, Kateryna Nahirska, Nataliia Pokotylska. Foresight...

Kytzia, S., Faist, M., \& Baccini, P. (2004). Economically extended - MFA: a material flow approach for a better understanding of food production chain. Journal of Cleaner Production, 12(8-10), 877-889. https://doi.org/10. 1016/j.jclepro.2004.02.004

Lemetti, Yu. A., \& Kelebay, M.R. (2016). Model forsayt-platformy kak instrument formirovaniya effektivnoy agrarnoy politiki regiona. Mezhdunarodnyy nauchnyy zhurnal, 4, 33-35.

Martin, S. J., \& Clapp, J. (2015). Finance for agriculture or agriculture for finance? Journal of Agrarian Change, 15(4), 549-559. https://doi.org/10.1111/joac.12110

Martin, B.R. (1995). Foresight in science and technology. Technology Analysis and Strategic Management, 7, $139-168$. https://doi.org/10.1080/09537329508524202

Matthews, A. (2012). The changing landscape of agricultural support. Written by Blog posts. Retrivied from http://capreform.eu/the-changing-landscape-of-agricultural-support/anuary

Portna, O. V. (2013). Sukupnyi finansovyi potentsial krainy: systemnyi pidkhid. Biznes Inform, 9, $293-298$.

Portna, O. V. (2017). Arkhitektonika sukupnoho finansovoho potentsialu Ukrainy: pozytyvni synerhetychni efekty ta sukupni ryzyky. Problemy ekonomiky, 1, 122-127.

Prokopyshak, V. B. (2016). Metodyka formuvannia finansovoho potentsialu ahrarnykh pidpryiemstv. Naukovyi visnyk NLTU Ukrainy, 2, 162-168.

Radchenko, O. D., \& Lazutina, L. O. (2018). Metodolohichni osnovy formuvannia finansovo-kredytnoi infrastruktury ahrarnoho sektoru. In: Nepochatenko O.O. (Ed.), Stan ta umovy rozvytku ekonomiky v Ukrainy: teoriia, metodolohiia, praktyka: monohrafiia (pp. 97-103). Uman: Vydavets Sochinskyi M. M.

Radchenko O. D. (2019). The financial potential of sustainable development of the agricultural sector. Economics of agriculture, 1, 27. https://doi.org/10.32317/2221-1055.201901027

Shevchenko, E. V., \& Stukach, V. F. (2017). Perspektivy razvitiya selskokhozyaystvennogo sektora v Kazakhstane: rezultat Natsionalnogo forsayt-proyekta potentsial razvitiya agroprodovolstvennogo kompleksa: sotsialnyy kapital. innovatsii. proizvodstvo. mezhdunarodnaya integratsiya, pp. 148-155.

Trusova, N.V. (2017). Finansovyi potentsial sub'iektiv hospodariuvannia ahrarnoi haluzi. Melitopol: TOV «Vydavnychyi budynok MMD.

Martinaityte, E. (2009). Conceptual Framework for Foresight Development. Intellectual Economics, 2(6), $73-82$.

Kalle A. Piirainen, Rafael A. Gonzalez (2015). Theory of and within foresight - "What does a theory of foresight even mean?". Technological Forecasting and Social Change, 96, 191-201. https://doi.org/10.1016/ j.techfore.2015.03.003

Lu, Louis Y.Y., Hsieh, Chih-Hung, \& Liu, John S. (2016). Development trajectory and research themes of foresight. Technological Forecasting and Social Change, 112, 347-356, ISSN 0040-1625, https://doi.org/10.1016/ j.techfore.2016.07.040.

Nemeth, B., Dew, N., \& Augier, M. (2018). Understanding some pitfalls in the strategic foresight processes: The case of the Hungarian Ministry of Defense. Futures, 101, 92-102, ISSN 0016-3287, https://doi.org/10.1016/j.futures. 2018.06.014.

Andersen, A.D., \& Andersen, Per D. (2017). Foresighting for inclusive development. Technological Forecasting and Social Change, 119, 2017, 227-236, ISSN 0040-1625, https://doi.org/10.1016/j.techfore.2016.06.007.

Rhisiart, M., Stormer, E., \& Daheim, C. (2017). From foresight to impact? The 2030 Future of Work scenarios. Technological Forecasting and Social Change, 124, 203-213, https://doi.org/10.1016/j.techfore.2016.11.020.

Aguirre-Bastos, C. \& Weber, M.K. (2018). Foresight for shaping national innovation systems in developing economies. Technological Forecasting and Social Change,128, 186-196, https://doi.org/10.1016/ j.techfore.2017.11.025.

Pietrobelli, C., \& Puppato, F. (2016). Technology foresight and industrial strategy. Technological Forecasting and Social Change, 110,117-125. https://doi.org/10.1016/j.techfore.2015.10.021

Bourgeois, R., \& Sette, C. (2017). The state of foresight in food and agriculture: Challenges for impact and participation. Futures, 93, 115-131. https://doi.org/10.1016/j.futures.2017.05.004

Wonglimpiyarat, J. (2007). National foresight in science and technology strategy development. Futures, 39(6), 718-728. https://doi.org/10.1016/j.futures.2006.11.005

Foresight (2007-2019). Journal of the National Research University Higher School of Economics. ISSN 1995-459X EISSN 2312-9972 https://foresight-journal.hse.ru/en/

The article has been reviewed.

Received in October 2019; accepted in April 2020. 